\title{
Dinamika Perguruan Tinggi Islam dan Tantangan Masa Depan
}

\author{
Ismail Suardi Wekke \\ Sekolah Tinggi Agama Islam Negeri (STAIN) Sorong, Indonesia \\ University College of Yayasan Pahang, Malaysia \\ Email: iswekke@gmail.com
}

\author{
International Postgraduate Research Conference (IPRC) \\ Universitas Negeri Padang and Southeast Asia Academic Mobility (SEAAM) \\ In Conjunction with \\ International Conference on Social Studies, Globalization, and Technology \\ Padang, 3-6 October, 2019
}

\begin{abstract}
ABSTRAK
Perguruan tinggi bukanlah sekadar kelanjutan dari pendidikan menengah. Namun, perguruan tinggi menjadi wahana untuk pengembangan keilmuan secara luas. Tidak pula hanya berdiam diri dalam proses pendidikan yang semata-mata untuk ilmu semata. Melainkan, terdapat tanggungjawab sosial yang melekat dalam perguruan tinggi untuk melihat aspek secara luas. Artikel ini mendeskripsikan dua hal bagaimana perguruan tinggi saat ini dan tantangan yang akan dihadapi di masa depan yang bahkan saat ini sudah menjadi dinamika sehari-hari.
\end{abstract}

Kata Kunci: pendidikan tinggi; perguruan tinggi; tata kelola abad dua satu.

\section{Pendahuluan}

Apa pertanyaan yang diajukan ketika bertemu dengan kolega sesama pimpinan perguruan tinggi? Diantara pertanyaan yang muncul yaitu "berapa jumlah mahasiswa?" "berapa luas lahan kampus?". Dua pertanyaan itu muncul jika diskusinya merupakan cerminan abad 20. Sekarang kita di abad 21, generasi milenial sudah masuk ke angkatan kerja. Sementara generasi Z sudah mulai duduk di bangku kuliah. Obrolan tidak sekedar menghitung jumlah mahasiswa dan luas kampus. Namun, lihat performance kampus di sisi dunia maya. Lebih luas lagi dalam platform digital. Dimana kehidupan abad 21 menempatkan realitas sehari-hari yang juga bersemayam dalam bentuk digital. Luas kampus tidak lagi menjadi hitungan di jagad maya. Tetapi bagaimana kampus dikenal dengan jejak-jejak digital.

Maka, obrolan tentang jumlah mahasiswa dan luas kampus akan mengidentifikasi topiktopik "pemetaan di SINTA", "keberadaan di Google Scholar", dan "kewujudan di pangkalan data bereputasi". Itu pulalah yang menjadi kriteria di borang akreditasi baik program studi maupun perguruan tinggi. Bahkan secara khusus, salah satu kriteria memerlukan capaian output tri dharma perguruan tinggi. Tabel yang perlu dikemukakan pengelola perguruan tinggi melalui program studi antara lain "penerbitan", "penelitian", "pengabdian masyarakat", kesemuanya terintegrasi dengan perkuliahan. Bahkan dalam tabel isian, nama mata kuliah juga perlu dicantumkan.

\section{Dinamika Perguruan Tinggi Islam}

Era integrasi keilmuan yang dicanangkan dengan pembentukan Universitas Islam Negeri Syarif Hidayatullah, Jakarta dimulai dengan peresmian kelembagaan UIN pada tahun 2002. 
Disusul dengan UIN lainnya yang saat ini sudah berjumlah tidak kurang 18 lembaga. Menyusul 11 IAIN yang sementara disiapkan menuju UIN. Sekarang, perlu dilihat sejenak, alumni Fakultas Sains dan Teknologi lulusan perguruan tinggi umum dan lulusan UIN, “apa bedanya?". Padahal, niatan awal yang melandasi alasan UIN perlu didirikan adalah dalam rangka membentuk sarjana yang tidak hanya menjadikan Islam sebagai amalan ibadah semata tetapi juga wujud dalam bentuk ilmu pengetahuan.

Tidak hanya di UIN, tetapi juga perlu dilihat sejenak bagaimana perguruan tinggi dalam koordinasi Nahdhatul Ulama, Muhammadiyah, Mathlaul Anwar, Alkhairat, dan Alwasliyah. Semuanya mengelola Fakultas Agama Islam. Hanya saja, "apa tidak terjebak pada monodisiplin?". Secara administratif, sudah tidak ada pembeda antara Sarjana Pendidikan Islam dengan Sarjana Pendidikan. Semuanya menjadi Sarjana Pendidikan. Tanpa perlu embel-embel Islam. Eksperimen untuk sampai ke situ memerlukan waktu tidak kurang dari dari Sembilan belas tahun. Suatu masa pernah S.Ag., lalu menjadi S.Pd.I., kemudian menjadi S.Pd. Maka, dengan semua keruwetan yang terjadi perlu ditetapkan bahwa agenda utama perguruan tinggi Islam adalah integrasi keilmuan.

Sebelum melihat lebih jauh di negara tercinta, Indonesia. Mari melihat eksperimen di dunia Islam. Universitas Islam Antarbangsa di Malaysia dan Islamabad, menunjukkan bahwa ada upaya untuk menempatkan Islam sebagai bagian dari keilmuan. Maka, kita simak di kurikulum dan percakapan alumni kedua perguruan tinggi tersebut dimana maqashid shariah dijadikan sebagai landasan keilmuan. Peran-peran global mulai dimainkan oleh alumni kedua perguruan tinggi ini.

Warisan yang sudah berdiri berabad-abad, Al-Azhar, sejak Dinasti Fatimiyah pada tahun 297 H. Doktrin Azhar menjadi khutbah yang sejak awal diperkenalkan kepada mahasiswa. Proses pembelajaran yang berlangsung di kelas-kelas Syekh Azhar juga mengundangkan doktrin-doktrin Azhar yang berorientasi pada penyebaran misi Islam yang Rahmatan lil Alamin. Sehingga setiap alumni Azhar mengumandangkan Islam yang moderat. Dalam istilah kurikulum kita menyebutnya Capaian Pembelajaran. Perguruan tinggi kita, kadang tidak merumuskan CP ini secara spesifik. Bahkan terkadang hanya menjadi hiasan dalam kertas kerja atau dokumen semata. Belum diaplikasikan secara detail dalam aktivitas keseharian.

Lalu, lulusan UIN apa yang bisa menjadi tanda penciri yang berbeda dengan alumni perguruan tinggi umum? Waktu yang akan menjawabnya. Suatu saat, perlu dilakukan survey ketika angka 2022 dijejak. Saat itu, sudah dua dekade perjalanan UIN. Sementara IAIN yang sekarang ini diproyeksikan untuk alihstatus menjadi UIN perlu berbenah sejak awal bagaimana mengawal transformasi kelembagaan UIN tidak sekadar berganti nama tetapi juga mengawal Islam Indonesia sehingga akan memerankan fungsi-fungsi global yang tidak dilepaskan dari peran-peran kemasyarakatan dalam skala lokal.

\section{Tantangan Kini dan Masa Depan}

Senyampang membenahi infrastruktur yang belum ada dan menambahbaik apa yang sementara ada, maka tantangan pembangunan perguruan tinggi di masa depan semakin mencabar. Pertama kalau di dunia nyata ukuran lahan yang digunakan, maka salah satu parameter perguruan tinggi adalah pengelolaan website. Jika laman web tidak bisa ditemukan, maka akan menjadi tanda tanya. Reputasi perguruan tinggi terkadang dilihat dari awal bagaimana maklumat yang tersedia di website. Tentu terkait pula dengan bandwith dan piranti 
lunak lainnya. Begitu pula dengan digital library, repository, ejournal, dan juga pengarsipan online lainnya.

Kedua, dengan alasan yang sangat pragmatis, penggunaan kertas mulai dikurangi. Untuk skripsi, atau tesis, atau disertasi tidak perlu dicetak sampai tujuh eksemplar. Cukup dengan satu eksemplar saja kemudian diunggah juga ke dalam repository. Namun, perangkat lunak yang direkomendasikan seperti eprint. Dimana software ini yang utama gratis, juga terkait dengan kemudahan koneksi ke Google dan Google Scholar. Jika menggunakan Omeka, maka itu hanya sebagai display semata. Untuk pencarian menggunakan Google maupun terbaca di Google Scholar memerlukan waktu. Pengurangan penggunaan kertas juga akan mengurangi penebangan pohon. Maka, ini tentu menjadi bagian dari amalan muslim untuk tidak mubazir bukan saja hanya dalam soal makanan, tetapi juga sumber daya yang lain. Termasuk dalam penggunaan kertas. Sepanjang tidak urgent dan bisa disimpan di website, maka itu akan lebih mudah ditemukan berbanding jika harus dicetak.

Ketiga, melatihkan kemampuan kerja yang kolaboratif. Sejak awal ketika pembentukan departemen di struktur pemerintahan Indonesia, sudah jamak dilaksanakan dengan mengedepankan ego sektoral. Akibatnya, tidak terbiasa untuk saling menyapa dan berkolaborasi. Padahal, kecenderungan abad 21 pekerjaan perlu dilaksanakan dengan teknik sinergi. Mahasiswa dan juga dosen perlu dibiasakan untuk membuka diri menerima ide orang lain. Sementara ide yang dimilikinya perlu didialogkan. Sehingga dengan adanya dialog dan percakapan, akan memudahkan untuk saling membantu dalam mewujudkan tujuan bersama.

Sebagaimana pengelolaan jurnal yang tidak bisa dikelola secara internal saja. Bahkan harus melibatkan orang lain lintas institusi dan bahkan lintas negara. Dengan demikian, kemauan dan kemampuan melibatkan orang lain diperlukan sehingga jurnal dapat terbit secara berkala dan berkesinambungan. Setidaknya, ini salah satu contoh saja. Demikian pula cakupan yang lebih luas seperti akreditasi. Semuanya memerlukan keterlibatan dan dukungan pelbagai pihak. Jikalau hanya sendiri dan selalu tidak mau menyapa pihak lain, maka lambat laun kinerja perguruan tinggi tidak dapat dicapai. Apalagi kalau terjadi penumpukan kewenangan hanya pada satu orang. Ini juga menjadi preseden buruk bagi tata kelola perguruan tinggi.

Berikutnya, masjid tidak boleh hanya sekadar tempat sholat saja. Kalau ini terjadi, maka maksimal sehari-semalam hanya kurang lima jam saja penggunaan. Masjid di dalam kampus, perlu menjadi bagian integral kampus. Dijadikan sebagai laboratorium keagamaan, terintegrasi dengan proses pembelajaran. Sehingga ada perkuliahan yang juga menjadikan masjid sebagai ruang kelas. Sementara kaitan dengan pengabdian masyarakat, masjid menjadi tempat pelatihan dan juga laboratorium bisnis dan keuangan. Di masjid boleh digandengkan dengan toko buku atau tempat makan.

Masih dalam kaitan bangunan, menfasilitasi penyandang disabilitas untuk mengakses seluruh fasilitas kampus diperlukan sebagai tempat bersama. Setiap bangunan ada akses untuk kursi roda. Termasuk pula, setiap tangga yang menjadi kelengkapan bangunan perlu diberikan akses untuk pengguna kursi roda. Sampai pada perpustakaan, masjid, ruang belajar, dan bahkan juga sarana parker yang dikhusus untuk mereka. Di Malaysia disebut Orang Kurang Upaya (OKU). Bagi masyarakat kampus Malaysia, OKU mendapatkan perhatian yang sama dengan mahasiswa lainnya. Sehingga mereka bisa belajar tanpa perlu mendapatkan belas kasihan, karena semua fasilitas dapat diakses oleh mereka sendiri. Ini harus disediakan dan menjadi grand design pengembangan fisik kampus. Setiap lantai yang ada juga memberikan kemudahan dalam beraktifitas untuk semuanya. 
Satu hal lagi, perbedaan antara kampus luar negara dengan kampus Indonesia terletak pada bangunan rektorat. Secara khusus bangunan rektorat yang megah dengan seluruh fasilitas yang menjadi daya dukung. Sementara fasilitas ruang dosen ataupun perpustakaan serba terbatas. Untuk mengecek bangunan paling mewah di Indonesia, biasanya adalah gedung rektorat. Sementara perpustakaan hanya mendapatkan fasilitas seadanya. STAIN Sorong sudah memulai menempatkan perpustakaan di bagian paling depan kampus. Ini perlu dibarengi dengan penyusunan katalog induk Papua Barat. Sehingga tidak hanya bangunan yang megah tetapi juga sarana pendukung perpustakaan juga wujud sebagai bagian yang tidak terpisahkan.

\section{Keluasan Horizon Keilmuan}

Jika awal pendirian IAIN diwarnai oleh Azhar, itu terlihat dengan penggunaan nama fakultas seperti Adab, Syariah, dan Tarbiyah, maka fase berikutnya mendapat tambahan warna dari Canada melalui McGill University. Dosen-dosen melalui kerjasama Indonesia-Kanada disekolahkan di McGill. Pada kurun waktu tertentu, alumni McGill menjadi decision maker di pelbagai IAIN sehingga corak warna McGill terlihat dalam pembaruan kurikulum, dan juga tradisi pascasarjana. Jejak itu masih terlihat sampai sekarang di UIN Jakarta dengan kewajiban menjadikan tesis atau disertasi menjadi buku. Ini mengadopsi praktik yang dilaksanakan di McGill bahkan sampai pada ukuran kertas juga. Salah satu motor penggerak IAIN Jakarta ketika itu, Prof. Dr. Harun Nasution. Begitu pula Prof. Dr. Mukti Ali yang juga lulusan McGill.

Kehadiran Prof. Dr. Harun Nasution menjembatani dua khazaah keilmuan, Azhar dan McGill. Beliau lulusan di kedua lembaga tersebut. Sementara Prof. Dr. Mukti Ali baik sebelum dan bahkan sesudah menjabat Mentri Agama, beliau menginisasi program studi Perbandingan Agama. Alumni Pascasarjana UIN Jakarta yang tersebar ke seluruh Indonesia, satu persatu menjadi pucuk pimpinan. Hanya saja tradisi intelektual belum berkembang sebagaimana ketika mereka duduk di bangku kuliah Ciputat.

Perkembangan selanjutnya, walau bukan dalam bentuk pembibitan dosen, tenaga akademik perguruan tinggi Islam melanjutkan pendidikan di Australia. Sementara ini, ada dua rektor yang menyelesaikan pendidikan di Australia, IAIN Manado dan UIN Alauddin. Sehingga khazanah pendidikan tinggi, empat tahun ke depan akan diwarnai dengan perjumpaan tradisi Australia.

Melalui beasiswa ADS dan juga beasiswa AusAID, dosen-dosen perguruan tinggi Islam menempuh pendidikan di Australia. Termasuk program-program seperti PIES yang berlansgung secara intensif. Ini memberikan kesempatan bagi tenaga pengajar untuk berjumpa dan berinteraksi dengan tradisi perguruan tinggi Australia. Sepulang mereka ke lembaga masingmasing, menjadi peluang untuk memberikan penguatan dan juga berbagi pengalaman baik dengan mahasiswa maupun kolega.

Di awal tahun 2000, dosen-dosen dengan prakarsa sendiri menempuh pendidikan di pelbagai perguruan tinggi Malaysia. Di perguruan tinggi Malaysia tidak membentuk kajian Islam yang dipisah menjadi fakultas tersendiri. Kecuali di Universiti Kebangsaan Malaysia. Begitu pula di Universiti Malaya dibuat dalam bentuk Akademi Pengajian Islam Universiti Malaya. Sementara kampus lain, dibuat tersebar sesuai dengan fakultas yang ada dengan tidak menyebutnya sebagai kajian Islam. Secara terintegrasi kajian Islam tidak dipandang sebagai sebuah kajian semata, seperti Universiti Teknologi Malaysia yang bertempat di Johor. Sekalipun lebih fokus pada teknologi dan keilmuan eksakta, pusat kajian Islam yang ada di UTM melakukan integrasi keilmuan dengan pelbagai kajian keteknikan. Perjumpaan dengan perguruan 
tinggi Malaysia menjadi peluang untuk melihat cakrawala pendidikan tinggi dengan referensi yang beragam.

Secara terbatas beasiswa Chevening Award, Fulbright, Netherland Education Centre (NEC) juga diperoleh oleh dosen-dosen perguruan tinggi Islam. Tengaa kependidikan dan dosen yang ada berasal dari pelbagai kampus di seluruh dunia. Ketika dosen-dosen itu menempuh pendidikan di luar negara, mereka produktif dan memublikasikan karya-karya mereka di jurnal yang bereputasi. Sementara ketika mereka kembali ke Indonesia, justru mereka kembali kepada keadaan awal sebagaimana sebelum mereka berangkat ke luar negara. Berarti, kondisi dan iklim akademik di Indonesia yang belum memberi kesempatan untuk berkarya. Semua terjebak dalam urusan administratif.

\section{Pertanyaan Agenda Masa Depan}

Islam tidak bisa dilihat sebagai doktrin semata (Madjid, 1992) tetapi menjadi jalan hidup sekaligus sebagai bagian dari pengembangan ilmu pengetahuan. Lihatlah betapa perguruan tinggi Islam perlu mengangendakan keterpisahan dari radikalisme yang mulai merasuk ke pendidikan tinggi. Ini satu pekerjaan rumah tersendiri. Mampukah perguruan tinggi keagamaan Islam menjawab pertanyaan-pertanyaan yang belum ada dalam kitab-kitab fikih. Tetapi juga, jangan sampai meributkan sebuah isu yang justru karena kesilapan di awal proses riset. Beberapa agenda di masa depan terkait dengan media informasi (Wekke, 2018a).

Sementara masa depan studi Islam juga mendapatkan tantangan tersendiri dimana fakultas agama Islam menjadi bagian kecil dari UIN. Jurusan masih disebut dengan jurusan umum. Padahal sejatinya, sudah ada integrasi keilmuan yang dikembangkan. Lalu dimana posisi integrasi keilmuan itu akan wujud?. Amin Abdullah (2003, 2006, 2007, 2013, 2017) memberikan penegasan dalam integrasi keilmuan, tetapi itu hanya wujud sebatas di Yogyakarta. Lalu apakah perguruan tinggi keagamaan lainnya melakukan hal yang sama?. Saya khawatir jikalau itu tidak terjadi sama sekali.

Terakhir, bagaimana dengan peran-peran aktual pendidikan tinggi diwujudkan?. Kondisi masyarakat yang berbeda antara satu wilayah dengan wilayah lainnya. Seperti perguruan tinggi di Bali (Wekke, 2016), Manado (Wekke, 2017), Papua (Wekke, 2018b; Wekke, Kahar, \& Amri, 2018). Ini akan memberi kesempatan tersendiri bagi PTKI untuk menjadi bagian dari community based higher education. Memberikan kesempatan masing-masing merumuskan tipikal kelembagaan dapat menjadi alternatif bagi pengembangan perguruan tinggi. Sehingga tidak hanya monolitik dengan satu-satunya bentuk World Class University.

\section{Penutup}

Perguruan tinggi bukan sebatas rektorat dan bukan pula pada bangunan semata. Begitu pula tidak hanya sebatas bahwa kuliah dengan duduk di dalam ruangan kelas. Ada ruang-ruang yang bisajadi akan menjadi konvergensi sehingga pembelajaran perguruan tinggi mengikuti perkembangan dan pengembangan kondisi yang ada. Teknologi memberi kesempatan untuk meluaskan pandangan itu. Sementara rak-rak buku bukan lagi satu-satunya sumber pengetahuan. Rak-rak buku juga mulai tersedia dalam bentuk digital, bahkan repository kampus sudah menjadi kebutuhan tersendiri. Tidak harus berbiaya mahal, tetapi terdapat pilihan-pilihan yang tidak perlu berbayar sama sekali. Kecuali untuk keperluan jaringan internet dengan dukungan listrik yang memadai.

Perguruan tinggi perlu melakukan revitalisasi dan relevansi. Jangan sampai akan terkubur hanya karena tidak lagi relevan. Justru memberi kesempatan bagi adanya komunikasi lintas 
keagamaan, tetapi penguatan internal justru abai dilakukan. Ini menjadi masalah tersendiri. Laman web salah satunya, itu cerminan dari wajah perguruan tinggi dengan keberadaan internet. Namun juga bukan satu-satunya. Sebab kewujudan kampus berupa lahan tetap perlu didandani sehingga tersedia untuk semua warga, termasuk para penyandang disabilitas menjadi warga yang memiliki kesempatan yang sama untuk menikmati fasilitas pendidikan.

\section{Daftar Pustaka}

Abdullah, A. (2003). New Horizons of Islamic Studies Through Socio-Cultural Hermeneutics. Al-Jâmi'ah: Journal of Islamic Studies, 41(1), 1-24.

Abdullah, A. (2017). ISLAM AS A CULTURAL CAPITAL IN INDONESIA AND THE MALAY WORLD: A Convergence of Islamic Studies, Social Sciences and Humanities. Journal of Indonesian Islam, 11(2), 307-328.

Abdullah, M. A. (2006). Islamic studies di perguruan tinggi: pendekatan integratif-interkonektif. Yogyakarta: Pustaka Pelajar.

Abdullah, M. A. (2007). Islamic studies dalam paradigma integrasi interkoneksi: sebuah antologi. Yogyakarta: Suka Press.

Abdullah, M. A. (2013). Agama, Ilmu dan Budaya: Paradigma Integrasi-Interkoneksi Keilmuan. Jakarta: Akademi Ilmu Pengetahuan Indonesia.

Madjid, N. (1992). Islam: Doktrin dan Peradaban. Jakarta: Yayasan Wakaf Paramadina.

Wekke, I. S. (2016). Learning and Service Quality in Islamic Higher Education of Minority Muslim Bali. In International Conference on Ethics in Governance (ICONEG 2016). Atlantis Press.

Wekke, I. S. (2017). Arabic Teaching and Learning Material in Higher Education of Muslim Community North Sulawesi. Dinamika Ilmu, 17(2), 175-189.

Wekke, I. S. (2018a). Masa Depan Kajian Islam di Indonesia. https://doi.org/10.31227/osf.io/36tua.

Wekke, I. S. (2018b). Higher education governance of muslim minority: efforts to be part of nation's development. AKADEMIKA: Jurnal Pemikiran Islam, 23(1), 1-26.

Wekke, I. S., Kahar, M. S., \& Amri, I. (2018). Perguruan Tinggi Tanah Papua dan Strategi Pengembangan Pendidikan Tinggi. https://doi.org/10.31227/osf.io/m3kvb. 